\title{
Gain Weight, Have Fun, Discover the Motherland: The German-Polish Children's Summer Camp Exchange and Interwar Era Revisionism
}

\author{
Peter Polak-Springer (D) \\ Qatar University, Humanities Department, P.O. Box 2713, Doha, Qatar \\ ppspringer@qu.edu.qa
}

This article examines a previously un-researched aspect of nationalist politics, borderland contestation, national indifference and the politicisation of youth and cultural diplomacy in interwar Central Europe: the German-Polish 'summer vacation exchange for children' (Ferienkinderaustausch). The Versailles territorial settlement, which left nationalists in both countries in discontent about territories and minority groups remaining in the hands of the neighbour, formed the basis for this venture in cultural diplomacy. Each party gave the other the right to rally 'its youth' living on the other side of the border to travel to its 'motherland' for summer camp. Focusing on the case study of the heatedly contested industrial borderland of Upper Silesia, this article examines the German-Polish children's exchange on two levels. On the local level it examines how youth were rallied and transported to their 'motherland' for the summer and what treatment and experience they received. On the international level it explores the paradox of German-Polish cooperation and the conflict that was an inherent aspect of this venture.

In mid-July 1936 Ostland, the flagship publication of Nazi Germany's eastern borderland organisation, the Bund Deutscher Osten (BDO), published an article entitled 'German Children in Polish Summer Camps'. It noted the arrival of a special charter train to the border city of Beuthen in German Upper Silesia, which was returning home some 600 children who had attended summer vacation camps in Poland, which lay just a few kilometres to the east. It reported that upon leaving the train these children were speaking German rather than Polish with one another, and even with their Polish chaperones. From the article's standpoint, it was outrageous and nothing short of scandalous that German-speaking - or in other words, 'German' children - were spending their summer recess in Polish state youth camps. ${ }^{1}$ This anecdote exemplified a familiar discourse in a larger German and Polish contest to rally youth from the Upper Silesian border area for 'our' rather than the 'other's' summer camps. This contest for campers long predated the Nazis. An inherent part of interwar ethnic nationalism and irredentism in Central Europe's contested borderlands, this struggle was actually a product of German-Polish cultural diplomacy, which is the subject of this article.

In this article I examine the exchange of national minority youth during the school summer recess, a significant and until now unexplored German-Polish state cooperation which lasted from 1923 to 1938. This transnational effort in youth tourism was ultimately a product of the break up of the German and Austro-Hungarian empires into small nation states after the First World War. The borders of these states were the product of nationalist conflict, sometimes violence, and ultimately

\footnotetext{
1 'Deutsche Kinder in polnischen Ferienlagern', Ostland, in Karl Sczodrok to Nord- und Ostdeutsche Forschungsgemeinschaft (NOFG), 15 July 1936, Bundesarchiv, Berlin, (BArch), R, Reich, 153, 1302, n.p.

(c) The Author(s), 2020. Published by Cambridge University Press. This is an Open Access article, distributed under the terms of the Creative Commons Attribution licence (http://creativecommons.org/licenses/by/4.0), which permits unrestricted re-use, distribution and reproduction, provided the original article is properly cited.
} 
fiat from the Paris peace treaties. As a result, they were heavily contested as old and new nations called for a 'return' of the national brethren left stranded as national minorities on the other side. ${ }^{2}$

The youth exchange agreements allowed Germany and Poland to take these respective 'orphans of Versailles' on a month-long summer visit to their 'motherland' (i.e. the country where their national group constituted the majority). ${ }^{3}$ Every year each state worked to rally children living within the 'other's' national border to its summer camps. As I demonstrate below, this effort fuelled bilateral nationalist propaganda, conflict and aggression, and made borderland children pawns of interwar state irredentist politics. ${ }^{4}$ Paradoxically, however, this effort was launched in the spirit of peaceful cooperation and collaboration between states. A significant aspect of German and Polish cultural diplomacy, it exemplified how the latter was a tool of territorial contestation, nationalising populations across the border and promoting the ethnic nationalist spirit that marked the Zeitgeist of interwar European politics.

The geographic focus here is Upper Silesia. As evident in the German and Polish archival records upon which this article is based, this region was the prime object of official discussion, concern and controversy with regards to this youth exchange. A part of the province of Silesia, it had been part of Prussia in the pre-war German Empire. After the First World War, and due to its heavy industry, it became a contested borderland between the new republics of (Weimar) Germany and Poland. Initially the League of Nations prescribed Upper Silesia's national fate to its inhabitants, the Silesians, who voted to remain in Germany by a margin of almost 60 per cent. However, following an uprising (the 'third Silesian uprising') instigated by Polish nationalists, which captured much of the region's industrial areas by force, the Western Allies decided to divide the region in Poland's favour as part of their policy of limiting Germany's industrial potential. Drawn in 1922, this German-Polish border ran through the region's clustered urbanised industrial centres that had formerly constituted one single coal mining and metallurgy area and one single Silesian society. Germany retained the western part of this region - which I will refer to as German Upper Silesia - which included the border cities of Beuthen, Hindenburg and Gleiwitz. Poland gained the urban centres and area just east of them here Polish Upper Silesia - which included the cities of Katowice and Chorzów. Demands for the return of this formerly Prussian area marked a pivotal part of Weimar and later Nazi Germany's revisionist politics. Threatened by this revisionism, particularly since Polish Upper Silesia was the new Poland's most important coal mining and industrial region, Polish nationalists responded by advancing their own claims to additional areas on the German side of this border. ${ }^{5}$

\footnotetext{
2 See Rogers Brubaker, 'Aftermaths of Empire and the Unmixing of Peoples', in Rogers Brubaker, ed., Nationalism Reframed: Nationhood and the National Question in the New Europe (Cambridge: Cambridge University Press, 1996), 148-78; Jochen Böhler, Civil War in Central Europe, 1918-1921: The Reconstruction of Poland (Oxford: Oxford University Press, 2018); Tomas Balkelis, War, Revolution, and Nation-Making in Lithuania, 1914-1923 (Oxford: Oxford University Press, 2018); Timothy Snyder, Reconstruction of Nations: Poland, Ukraine, Lithuania, Belarus, 1569 (New Haven: Yale University Press, 1999), 133-53; Omer Bartov and Eric Weitz, eds., Shatterzone of Empires: Coexistence and Violence in the German, Habsburg, Russian, and Ottoman Borderlands (Bloomington: Indian University Press, 2013); Pieter M. Judson, The Habsburg Empire: A New History (Cambridge: The Belknap Press of Harvard University Press, 2018), 345-54; Aviel Roshwald, Ethnic Nationalism and the Fall of Empires: Central Europe, the Middle East, and Russia (London: Routledge, 2000); Alexander Prusin, The Lands in Between: Conflict in the East European Borderlands, 1870-1992 (Oxford: Oxford University Press, 2010), 72-124; Annemarie Samartino, The Impossible Border: Germany and the East, 1914-1922 (Ithaca: Cornell University Press, 2010).

3 'Orphans of Versailles' from Richard Blanke, Orphans of Versailles: The Germans in Western Poland, 1918-1939 (Kentucky: University Press 1993).

4 On children in borderland politics, see Machteld Venken, ed., Borderland Studies Meets Child Studies: A European Encounter (Frankfurt Am Main: Peter Lang, 2018); Elizabeth Harvey, Women and the Nazi East: Agents and Witnesses of Germanization (New Haven: Yale University Press, 2003), 23-43; Tara Zahra, Kidnapped Souls: National Indifference and the Battle for Children in the Bohemian Lands, 1900-1948 (Ithaca and London: Cornell University Press, 2008); Anna Novikov, Shades of a Nation: The Dynamics of Belonging Among the Silesian and Jewish Populations in Eastern Upper Silesia, 1922-1934 (Osnabrück: Fibre, 2015).

5 On the conflict over Upper Silesia, see Timothy Wilson, Frontiers of Violence: Conflict and Identity in Ulster and Upper Silesia, 1918-1922 (Oxford, 2010), 75-99, 133-58; T. Hunt Tooley, National Identity and Weimar Germany: Upper Silesia
} 
National minorities on both sides of the border were a central political concern of the ensuing bilateral conflict over this key industrial region. ${ }^{6}$ Those officially referred to as the 'ethnic Germans' (Volksdeutsche) in Polish Upper Silesia, like ethnic Poles in German Upper Silesia, were actually citizens of the respective nations they resided in. However, the neighbouring state claimed them as its nationals. As part of the stipulations of the convention regarding Upper Silesia that the two states signed in Geneva in 1922, Germany committed to protecting its Silesian citizens of Polish nationality and Poland its Silesian Volksdeutsche citizens. Part of the League of Nation's minority protection mission, this convention granted Silesians of all officially recognised ethnic/national (non-)orientations rights to maintain their own identity, language, culture, press, organisations and schools. ${ }^{7}$ International agreements of this kind meant that, if states wanted to pursue their often incompatible territorial and minority interests, they would need to do so by peaceful and diplomatic means. It was against this backdrop that states turned from the use of 'hard power' (e.g. the instigation of uprisings) to 'soft power', i.e. economic incentives and cultural initiatives, to shape the identities and loyalties of border populations to their favour. Although such efforts might not immediately come to mind when we think of cultural diplomacy today, they were an integral and, in fact, elevated part of cultural diplomacy in the interwar period. The Germans had a name for this specific nationalisation-oriented form of cultural politics: 'nationality politics' (Volkstumspolitik) and pursued them through a myriad of non-state and state actors. In fact, following the First World War, efforts connected to Volkstumspolitik made up over half of the German Foreign Ministry's cultural diplomacy budget and, as foreign minister Julius Curtius put it in 1930, stood 'as a leitmotif above all [cultural diplomacy] activity. ${ }^{8}$ In the interwar years museums, schools, the media, rallies, scholarship and even architecture and building projects became some of the favourite weapons of this variant of cultural diplomacy among European states. ${ }^{9}$

The German-Polish summer exchange that began in 1923 was an example of this sort of cultural politics. Yet it stands out for its uniquely transnational and reciprocal character. It exemplifies how, similar to cultural politics aimed at domestic borderlands, Volkstumspolitik was also pursued beyond state borders. ${ }^{10}$ As such, the summer exchange was a crucial part of what historian and political scientist of interwar Central Europe, Rogers Brubaker, refers to as 'external homeland nationalism': an effort to 'assert states' rights - indeed their obligations - to monitor the condition, promote the

and the Eastern Border, 1918-22 (Lincoln, NE, 1997); James Bjork, Neither German nor Pole: Catholicism and National Indifference in a Central European Borderland (Ann Arbor, MI, 2008), 214-66; Juliane Haubold-Stolle, Mythos Oberschlesien: Der Kampf um die Erinnerung in Deutschland und Polen, 1919-1956 (Osnabrück: Fibre, 2008); Peter Polak-Springer, Recovered Territory: The German-Polish Conflict Over Land and Culture, 1919-1989 (New York and Oxford: Berghahn Books, 2015), 29-33.

6 On the German minority, see Winson Chu, The German Minority in Interwar Poland (Cambridge: Cambridge University Press, 2014) and Blanke, Orphans. See also the literature on national indifference below.

7 See Mark Mazower, 'Minorities and the League of Nations in Interwar Europe', Daedalus, 126, 2 (Spring 1997), 47-63, Carole Fink, Defending the Rights of Others: The Great Powers, the Jews, and International Minority Protection, 1878-1938 (Cambridge: Cambridge University Press, 2019); Brendan Karch, 'A Jewish “Nature Preserve”: League of Nations Minority Protections and Nazi Upper Silesia, 1933-1937’, Central European History, 46, 1 (Mar. 2013), 124-60.

8 Entwurf zu der Rede des Herrn Reichsministers betreffend die Aufgaben der Kulturabteilung, 10 June 1930, Politisches Archiv des Auswärtigen Amtes, Berlin, Germany (PA-AA), R 61125.

9 For works on interwar Volkstumspolitik-oriented cultural politics, see Zahra, Kidnapped Souls, Robert Traba, “Wschodniopruskość": Tóżsamość regionalna i narodowa w kulturze politczynej Niemiec (Olsztyn: Borussia, 2007); Peter Oliver Loew, Danzig und Seine Vergangenheit: die Geschichtskultur einer Stadt zwischen Deutschland und Polen (Osnabrück: Fibre, 2003); Juliane Haubold-Stolle, Mythos Oberschlesien: Der Kampf um die Erinnerung in Deutschland und Polen, 1919-1956 (Osnabrück, 2008); Holly Case, Between States: The Transylvanian Question and the European Idea During World War II (Stanford: Stanford University Press, 2009); Jörg Hackmann, and Rudolf Jaworski, eds., Deutsche Ostforschung und polnische Westforschung im Spannungsfeld von Wissenschaft und Politik (Osnabrück: Fibre, 2002); Polak-Springer, Recovered Territory.

10 On interwar cultural diplomacy in Central Europe, see Zsolt Nagy, Great Expectations and Interwar Realities: Hungarian Cultural Diplomacy, 1918-1941 (Budapest: Central European University Press, 2017) and Shelley Baranowski, Strength Through Joy: Consumerism and Mass Tourism in the Third Reich (Cambridge: Cambridge University Press, 2004). 
welfare, support the activities and institutions, assert the right and protect the interest of 'their' ethnonational kin in other states.'11 However, to be able to pursue such cross-border nationalisation efforts, each state had to let the other practice its Volkstumspolitik on its own side of the border.

To hide their intrusive irredentist intentions, both sides promoted the children's exchange as a benevolent child welfare effort. The exchange was actually part of a larger domestic policy common to Germany, Poland and other European states, of taking city children from their polluted urban environment into natural fresh air settings, as well as providing health and nutrition to those from working class families. ${ }^{12}$ This child welfare effort integrated youth from across the border with those from within the nation and, particularly in the case of Poland, from migrant communities abroad. Despite its larger humanitarian mission, the more important goal for the children's exchange effort was that of promoting a spirit of German and Polish pan-nationalism by keeping national minority youth across borders culturally connected to their 'motherland'. This combination of nationalism, irredentism and child welfare politics was a hallmark of the German and Polish summer exchange programme.

At the same time the official mission of exchanging 'national minority' youth masked a far more complicated and contentious reality. Among a majority of Silesians there was no easy way to tell German from Pole. Some of the classic communal divisions that helped forge ethnic/national borders in Europe, such as language, religion or even social class, were not present among this mostly bilingual (Polish, German, Silesian), all-Catholic and proletarian border population. Indeed, even as more and more Europeans became 'card carrying members of distinct national communities ${ }^{13}$ by the twentieth century, Silesians remained uncommitted to any firm, consistent and exclusive (German or Polish) national identity. Rather, they were known to be fickle and even opportunistic in their outward displays of patriotic devotion, national belonging or state loyalty. ${ }^{14}$ They were not the only ones in Europe to display such lack of national commitment. Adopting a term originally used by nationalists, scholars have labelled this attitude 'national indifference'. But alongside a few other multilingual borderlands, such as Alsace-Lorraine or parts of the Sudetenland (Czech-German borderlands), (German-Polish) Upper Silesia, as Tara Zahra claims, was perhaps the most famous 'nationally indifferent' region of them all. ${ }^{15}$

The non-existent boundary between Germans and Poles in Upper Silesia made the children's exchange into something different than it was officially. Rather than a fair swap of bounded national minority group members, it became, in actuality, a struggle between German and Polish nationalists to forge this boundary in accordance to their own irredentist-political interests. Both sides saw this

11 Brubaker, 'Introduction', in Brubaker, ed., Nationalism Reframed, 5.

12 Laura Lee Downs, Childhoood in the Promised Land: Working-Class Movements and the Colonies de Vacances in France, 1880-1960 (Durham and London: Duke University Press, 2002) and Zahra, Kidnapped Souls.

13 Zahra, Kidnapped Souls, 5.

14 On national indifference in interwar Upper Silesia, see Bjork, Neither German nor Pole; Wilson, Frontiers of Violence; Andrzej Michałczyk, Heimat, Kirche und Nation: Deutsche und polnische Nationalisierungsprozesse im geteilten Oberschlesien (1922-1939) (Cologne: Böhlau, 2010); Brendan Jeffrey Karch, Nation and Loyalty in a German-Polish Borderland: Upper Silesia, 1848-1960 (Cambridge: Cambridge University Press, 2018); Tomasz Kamusella, Silesia and Central European Nationalisms: the Emergence of National and Ethnic Groups in Prussian Silesia and Austrian Silesia, 1848-1918 (West Lafayette: Purdue University Press, 2007); Polak-Springer, Recovered Territory.

15 Tara Zahra, Kidnapped Souls and 'Imagined Non-communities: National Indifference as a Category of Analysis', Slavic Review, 69, 1 (2010), 9 and 93-119; Maarten Van Ginderachter and Jon Fox, 'Introduction: National Indifference and the History of Nationalism in Modern Europe', in Ginderachter and Fox, ed., National Indifference and the History of Nationalism in Modern Europe (London: Routledge, 2019), 1-14; Chad Bryant, Prague in Black: Nazi Rule and Czech Nationalism (Cambridge: Harvard University Press, 2007); Richard Blanke, Polish-Speaking Germans? Language and National Identity Among the Mazurians since 1871 (Köln: Böhlau, 2001); Philipp Ther, 'Caught in Between: Border Regions in Modern Europe', in Weitz and Bartov, Shatterzones of Empires, 485-502; Chu, The German Minority; Pieter M. Judson, Guardians of the Nation: Activists on the Language Frontiers of Imperial Austria (Cambridge: Harvard University Press, 2006); Christopher Fischer, Alsace to the Alsatians? Visions and Divisions of Alsatian Regionalism, 1870-1939 (New York: Berghahn Books, 2014). See also works on national indifference in Upper Silesia above. 
unbounded reality as offering an opportunity to rally any child across the border for their camps. They did this by making tailored appeals to opportunism rather than patriotism. This all-for-grabs scenario fuelled conflict and frustration on both sides: on the one hand, there was anger and jealousy that the 'other' was taking children that could be 'ours'; on the other hand, the unresponsive, ambivalent and materialistic attitude of these children's Silesian parents still marked a major challenge for each side's rallying efforts. Moreover, this all-for-grabs scenario gave this contest over summer campers a twofronted character. German state agents and nationalist activists competed against Polish ones for just about any child on the 'other's' border area, while each side also struggled to win over the consent of nationally indifferent parents for their respective summer camps.

To better illustrate all these qualities, I start this article with an overview of the German-Polish schoolchildren's exchange as a whole, including its statistical, logistical and legal features, as well as aspects and contexts of this exchange that transcend the Upper Silesian focus of this article. In the second section, I turn to a more focused analysis of the everyday summer camp experience in Poland. (Unfortunately, existing records do not offer an equal depth of insight into the German case.) The third section analyses how national indifference, youth travel to Poland and the experience at Polish summer camps exacerbated German-Polish competition and fuelled bilateral controversies. In the final section, I examine the intensified and radicalised efforts Germans invested in rallying campers during the Nazi era, showing how this led to conflict and ultimately to the suspension of the children's exchange on the eve of the Second World War.

\section{An Overview of the Children's Exchange and its Relevant Agreements}

Polish state actors first started to bring 'Polish' children of German citizenship from German Upper Silesia to Poland in 1923, one year before the formal start of the German-Polish agreement on the exchange of schoolchildren for summer vacation. ${ }^{16}$ Throughout the interwar era the main agent behind this effort was the Defence League for the Western Borderlands (Związek Obrony Kresów Zachodnich; ZOKZ, referred to hereafter as the Defence League), the most important organisation for 'Polonising' (nationalising) Poland's formerly Prussian borderlands. ${ }^{17}$ The Defence League's agent in Germany for this effort was the Association for the Aid of Children and Youth in Germany (Towarzystwo Pomocy Dziecka i Młodzierzy w Niemczech). On the German side, the Prussian state government, the Reich Office for Country Visits for City Children (Reichzentrale für Landaufenthalt für Stadtkinder) and the German Welfare Service (Deutsche Wohlfahrtsdienst) were the leading agents. Moreover, on both sides, religious institutions, such as the German Caritas and the Polish Catholic School Association (Polski-Katolicki Zwiazek Szkolny), were also active in the children's exchange. ${ }^{18}$ German and Polish minority organisations, the Volksbund in Polish Upper Silesia and the Association for Poles in Germany (Związek Polaków w Niemczech; ZPwN), were likewise engaged.

According to Polish Defence League records, between 500 and 650 children travelled from German Upper Silesia to Poland each summer during 1925 to 1937, with the exception of 1929 to 1931, when the average attendance rose to close to $800 .{ }^{19}$ Until 1926 Poland rallied at least twice the amount of children that its German competitor drew from Polish Upper Silesia. ${ }^{20}$ This changed radically after

16 'Polnische Behörden als "Kinderfreunde"', Ostdeutsche Morgenpost, 191 (14 July 1939), n.n.

17 Polski Związek Zachodni (PZZ), Sprawozdanie z akcji koloni letnich dla dzieci . . 1938 (Lwów, PZZ 1939), 4. The ZOKZ changed its name to the PZZ in 1934.

18 Reichszentrale Landaufenthalt für Stadtkinder (RZLfSK) to Preußischer Minister des Innern (Pr. MdI), 25 Jan. 1933 , Politisches Archiv des Auswärtigen Amtes, Berlin, Germany (PA-AA), Warschau 176, Deutsches Botschaft in Warschau, n.p.

19 PZZ, Sprawozdanie z akcji kolonii . . . 1938, 4; Sprawozdanie z akcji kolonijnej Związku Obrony Kresów Zachodnich za Rok 1931 (Poznań, 1932), 7; Kolonie Letnie Związku Obrony Kr. Zachodnich, 1923-1927 (Poznań 1928), 8; Sprawodzdanie z akcji kolonialnej ZOKZ, 1929-1930 (Poznań 1931), 8.

20 Deutsche Wohlfahrtsdienst Kattowitz (Wohlfahrtsdienst), 'Ferienaufenthalt von Kinder der deutschen Minderheit in Ost-Oberschlesien', 6 Apr. 1929, PA-AA, R31044, Geheimakten 1920-1936, Microfiche (MF) 1, 22. 
1927, when the Germans rallied three to four times more children from Poland than Poland did from Germany. In fact, the number of children from Polish Upper Silesia going to Germany rose steadily from 1,501 in 1927 to 6,380 in $1935 .{ }^{21}$ Each side's campers from Upper Silesia were overwhelmingly Catholic - as were over 90 per cent of this region's native inhabitants. Protestant children, who were part of the German minority in Polish Upper Silesia, made up about a quarter of children travelling to Germany, according to German state records from 1929 and 1930. These same records also show that barely more than a handful of Jewish children - ten in 1929 and thirty-seven in 1930 - also joined them. ${ }^{22}$ Beyond this document, neither side made any explicit mention of Jewish children. Jews were a small minority in Upper Silesia and were hardly significant in the political conflict over it for most of the interwar era. ${ }^{23}$

The Germans' efforts to rally children to their summer camps enjoyed the advantages of larger size and better organisation. The urban status of its German minority organisations in Polish Silesia also helped, since transporting city children to the countryside for fresh air marked a core common purpose of the exchange programme. However, in the late twenties the Germans gained the edge in rallying children in large part due to the Polish government's campaign to 'Polonise' (and 'de-Germanise') state industry and institutions. ${ }^{24}$ As part of this persecution of Germans in Poland, the government of Polish Upper Silesia manipulated census data to decrease the number of German minority schools. ${ }^{25}$ Silesians targeted with job layoffs and prevented from sending their children to German schools often turned to the Volksbund for economic and cultural support, and this support included a subsidised or even free summer vacation for their children in Germany. ${ }^{26}$

Officially, child welfare marked a major concern of the children's exchange. In Germany and Poland this youth vacation effort was not just part of these states' foreign affairs, nor was it exclusively for children from across the border. Rather, it was also a part of their respective domestic policies to promote summertime health and nutrition - and not just culture and patriotism - among youth living inside and outside their borders. This policy belonged to a larger European tradition of raising children - culturally and physically - for the nation that predated the First World War. In her study of summer camps (colonies de vacances) in France, Laura Lee Downs demonstrates that these promoted a humanitarian mission of providing fresh air and hygiene in a natural and rural setting, especially to children from underprivileged industrial working-class families. ${ }^{27}$ Closer to this essay's border conflict theme is the work of Tara Zahra, who makes reference to summer camps as one of an array of institutions (including schools, day-care centres, kindergartens, nurseries and orphanages) used by Czech and German nationalists in their competition for the hearts and minds of children in the Bohemian borderlands. As Zahra points out, these Czech-German child welfare politics grew out of a long tradition of nationalist activist interference in child-rearing practices designed to ensure that these were patriotic and in accord with national interests. ${ }^{28}$

A similar nationalisation-oriented welfare mission was behind the German-Polish summer exchange. Both sides targeted urban youth from economically disadvantaged families - particularly during the Great Depression years - to provide them with fresh air, nutrition, sport and recreation, as well as national culture and patriotic spirit in the natural settings of rural, mountainous or seaside

21 Wohlfahrtsdienst, report, 27 May 1936, PA-AA, Kattowitz 63A, Deutsches Generalkonsulat Kattowitz (Deutsches Konsulat Katt.), 95h.

22 Wohlfahrtsdienst, report for 1929 and 1930, PA-AA, R 31044, MF 4, 151.

23 On Upper Silesia's Jews, see Novikov, Shades of a Nation, Wojciech Jaworski, Ludność żydowska w województwie śląskim w latach 1922-1939 (Katowice: Uniwersystet Śląski, 1997).

24 See, Ibid., 44-5 and Franciszek Serafin, Województwo Sląskie: Zarys Monograficzny (Katowice: Uniwersystet Śląski, 1996), 255-67.

25 Deutsches Konsulat Katt. to Auswärtige Amt, 17 Febr. 1930, PA-AA, R 31044, MF 3, 87.

26 RZLfSK, Report for 1931, PA-AA, R 31044, MF 4, 151.

27 Laura Lee Downs, Childhood in the Promised Land: Working-Class Movements and the Colonies de Vacances in France, 1880-1960 (Durham: Duke University Press, 2002).

28 Zahra, Kidnapped Souls, 9, 51, 112 and Harvey, Women and the Nazi East, esp. 23-43. 
areas. Children from across the border attending these camps joined a larger number of peers from within the nation, including from border and mainland regions. They also joined children from other areas, who travelled to Germany or Poland based on their separate exchange agreements with other countries. As part of its children's exchange agreements with Germany, the Polish state also drew a significant number, and sometimes even the bulk, of its children from among its labour migrant diaspora living in the industrial Ruhr district of Westphalia. In the summer of 1929 the number of these children from the Ruhr was far greater $(1,943)$ than those from German Upper Silesia (870) or the smaller number coming from other eastern border areas of Germany, such as East Prussia (Warmia and Mazuria) (73) or the Posen-West Prussia border region (Grenzmark PosenWestpreußen) (77). ${ }^{29}$ While these Ruhr urban children were officially of a far more clear-cut Polish national status than youth from German Upper Silesia and the other border areas, the Polish state treated them all as part of its national minority in Germany. Its agents thus sent them to Poland for health and nutrition, as well as for immersion in national culture (language, songs and history) and integration with their peers in Poland. With regard to summer youth exchanges, social policies and cultural diplomacy went hand in hand.

The German party to the exchange agreements likewise used these for more than just importing children from Polish Upper Silesia. Like Poland, Germany also brought over children from its neighbour's other border regions. For example, in 1929 the total arriving from the districts of the Poznan (Posen-Westpreussen) and Lódz $(2,000)$ was slightly higher than from Polish Upper Silesia $(1,800) .^{30}$ The German state also used the agreements for something unique: to reunite youth living in Germany with their families residing in Poland, especially in Polish Upper Silesia. Each year it sent a certain number of children (for example 700 in 1931) to this region to spend the summer with their relatives living there. ${ }^{31}$ However, this effort was also criticised by some German government officials, who never fully trusted the patriotic commitment of these Volksdeutsche relatives in Polish Silesia and thought they would only have a bad influence on these youth. Some officials also feared the negative effects of exposing these children from Germany to a Polish-speaking social setting. ${ }^{32}$

The concern about the patriotic qualifications of Silesians was common among German and Polish state agents. To both, Upper Silesia was the most significant region as far as the children's exchange was concerned. Surviving records on the exchange on both sides deal mostly with this borderland, a major hotspot of what was officially referred to as minority politics. As a key tool of such politics, the children's exchange was of fundamental political importance and distinguished from any other German/Polish summer vacation efforts and youth exchanges. According to a 1930 statement by the German Embassy in Warsaw, 'the whole German-Polish children's exchange is about something entirely different than the children's exchange with other countries, namely each side's minority politics' ${ }^{33}$

However, minority politics in Upper Silesia took on a different character than in other GermanPolish borderlands, where factors such as religion and language helped to consolidate and clarify ethnic/national communal borders. There were no significant cultural, confessional, linguistic or ethnic/ national differences between Silesians on either side of this borderland, and the official state border drawn in 1922 had not created them. The mostly bilingual and almost all-Catholic population also tended to lack any strong identification with, or one-sided patriotic commitment to, either Germany or Poland. Considering firm, unequivocal and prioritised national identity to be the norm of healthy social behaviour, German and Polish nationalists considered Silesians a 'layer in between' that lacked a 'pure and crystallised national soul' and recognised in them an 'unfortunate

29 RZLfSK, Report for 1929, PA-AA, R 31044, MF 3, 80.

30 Ibid., 81.

31 RZLfSK, Report for 1931, PA-AA, R 31044, MF 4, 151.

32 Pr. MdI., Ferienkinderaustausch mit Polen 1933, 14 June 1933, Archiwum Państwowe, Opole, Poland (APO) 1 Oberpräsidium der Provinz Oberschlesien, 155, 80 and Oberpräsident der Provinz Oberschlesien (OP) to Pr. MdI., 2 Juni 1933, APO 1, 155, 82.

33 Deutsche Gesandschaft Warschau, 10 Apr. 1930, PA-AA, R 31044, MF 3, 103. 
national double-splintering. ${ }^{34}$ However, they saw this not only as a challenge but also as an opportunity. 'Minority politics' in this region sought not only to protect existing minority members, but also to win over the hearts and minds of the nationally indifferent Silesian majority. Hence, just about any Silesian became a target for Germanisation and Polonisation. Minority politics turned into nationalisation politics. On each side of the border, German and Polish nationalists competed against one another to rally local participation for their schools, clubs and cultural events.

An important case in point was the annually-recurring struggle between German and Polish nationalists to rally parents to enrol their children in their respective (majority/minority) schools. ${ }^{35}$ As Tara Zahra's work shows, a similar contest raged between Czech and German nationalists in the Bohemian borderlands before and after the First World War. ${ }^{36}$ In both cases, the absence of clear distinctions between nationalities made for a situation in which each national camp of school activists competed for almost any child. The German-Polish children's exchange was in many ways similar. It, too, owed its fierce and conflict-ridden character to the difficulties and frustrations faced by activists on both sides in getting nationally indifferent parents to cooperate with and commit to their cause. ${ }^{37}$ Yet while school enrolments were largely domestic issues, the contest over summer campers was fundamentally transnational, involving cross-border travel and bilateral diplomatic negotiations.

This cultural diplomacy driven by nationalist antagonism marked another distinctive feature of the children's exchange. Paradoxically, Upper Silesia was not just a standing object of conflict but also a place of cooperation between Germany, Poland and the League of Nations, particularly with regard to the enforcement of the Geneva Convention of 1922, which guaranteed the protection of minorities living on both sides of this nationally divided region. The Wilsonian spirit behind this international agreement prescribed the protection of German and Polish minorities who lived on the other side of the border, as well as their language, schools, cultural institutions and their rights to selfdetermination. Translated into Upper Silesia's borderless social reality, this protection actually gave Silesians on each side of the border the right to join (or not join) any side's (majority/minority) national culture, events and institutions, and to do so interchangeably. In essence, it protected their right to remain uncommitted to any one nationality.

Officially, the German-Polish children's exchange agreements promoted a similar Wilsonian worldview. Almost every year German and Polish activists met at a special conference to plan the children's exchange for the coming summer. Existing protocols mostly shed light on both parties' concerns with the transborder logistics of the exchange. However, broader official correspondence, in particular records on the concerns and controversies that arose from the exchange effort, show that it was based on two core ground rules. For one, each side agreed to only take 'its' children and not those of the 'other'. Second, it agreed not to subject these children to politics and propaganda aimed against the neighbouring nation, or any other effort to turn them against their country of residence and citizenship. ${ }^{38}$ In fact, both sides worked to give the exchange a harmonious and even apolitical façade. They promoted an official concept of the effort as a peaceful 'cultural and humanitarian service rendered by the majority states [Germany/Poland] towards their minorities on the other

34 Zjazd ZOKZ w Suwałkach, 22 Apr. 1928, APK 27/I ZOKZ, 54, 9; Pr. MdI to OP, 20 Mar. 1935, APO 1, 155, 170; Milbradt to Wohlfahrtsdienst, 26 May 1936, PA-AA Kattowitz 63A, 95d; ZOKZ, działalność kulturowo-óswiatowa, APK, 38/I, Policja Województwa Śląskiego, 153, 168.

35 On minority schooling see Matthias Kneip, Die deutsche Sprache in Oberschlesien: Untersuchungen zur politischen Rolle der deutschen Sprache als Minderheitensprache in den Jahren 1921-1998 (Dortmund: Forschungsstelle Ostmitteleuropa, 2000), 75-115; Blanke, Orphans, 103-5.

36 Zahra, Kidnapped Souls, 13-47, 111-41.

37 See also Zahra, Kidnapped Souls, 5-6.

38 Deutsches Konsulat Katt., Ferienkinder Austausch, 15 July 1929, PA-AA Warschau, 176, n.p; RZLfSK to Pr. MdI, 15 July 1929, R 31044, MF 2, 42; Oberpräsidium (OP) records from 1932 in APO 1, 155, 67-71; RZLfSK to Towarzystwo Pomocy Dzieciom, 24 Aug. 1933, PA-AA Warschau, 176, n.p. 
side'. ${ }^{39}$ Moreover, they both emphasised the exchanges' promotion of child welfare rather than any political goal. ${ }^{40}$ This is why German and Polish child welfare activists, rather than formal government or embassy representatives, led the annual children's exchange conferences. ${ }^{41}$ Such official peaceful, charitable and apolitical qualities made the children's exchange agreement legal and legitimate before international law.

In spite of this emphasis on the summer exchanges' benevolent and tranquil qualities, both parties understood that, ultimately, they were part of an irredentist struggle to nationalise children in a contested region. To be able to engage in this struggle, each side had to allow its competitor to do so as well, or, in other words, give it the right to rally children from its side of the border for nationalisation and irredentist purposes. Both considered this reciprocal sacrifice to be necessary and worthwhile. The German Welfare Service refuted official concerns about losing children to Poland with the following statement: 'if in fact there are some cases when the children are won over for Polishdom [Polentum], such isolated cases are not tragic when one considers the great advantages given to German children in Poland by the children's exchange'. ${ }^{42}$ For both sides, such risks were worth taking for the sake of the effort to prevent the competitor from 'de-nationalising' - nationally assimilating - children on its side of the Upper Silesian border. German state agents hoped that the exchange effort would counteract the 'Polonisation' of youth in Polish Upper Silesia, especially after the Polish government closed some of the German minority schools in the 1930s. ${ }^{43}$ Moreover, both sides worried not only about the 'other's' nationalisation politics but also about harmful parental influence. They were concerned that particularly during the school recess parents would have a negative linguistic, cultural and patrioticsentimental impact on children. ${ }^{44}$ What Zahra argued with regards to Czech and German nationalists in the Bohemian borderlands was also the case in Upper Silesia: German and Polish state activists did not trust children's upbringing to their nationally indifferent parents. ${ }^{45}$ As a result, the two sides shared a common conception of the summer camps as a holiday substitute of sorts for (majority/ minority) schools. A look at the everyday workings of the Polish summer camps shows the extent to which these fulfilled this nationalising function.

\section{The Everyday Experience in Polish Summer Camps and its Discontents}

Recruiting children in German Upper Silesia for the summer camps in Poland was a constant challenge for the Polish state and its nationalist activists. Aided by the Polish-language press in German Upper Silesia, Polish activists lobbied parents to sign their children up for summer camp in Poland. These agents knew quite well that appeals to being 'a good Pole' were of limited effect, especially in this nationally indifferent region. According to one Defence League coordinator, here 'parents' national interest is often determined by material interests'. ${ }^{46}$ To adapt to this social environment, nationalists attempted to sell the summer camp experience the way a travel agency would: they promised parents an exciting, restful, healthy, invigorating, educational and, above all, memorable, vacation for their children, with these qualities guaranteed by the Polish state - and all

\footnotetext{
39 Page 3 of the protocol of the Deutsch-Polnisch Konferenz betr. Kinderaustausch in Warschau, 14. Apr. 1930, PA-AA Warschau, 176, n.p.

40 Deutsches Konsulat Katt., Ferienkinder Austausch, 15 July 1929, PA-AA Warschau, 176, n.p.; Deutsche Gesandschaft Warsaw, 10 Apr. 1930, MF 3, 102; Pr. MdI. to OP, 23 June 1932, APO 1, 155, 58; Deutscher Wolfahrtsdienst, 27 May 1936, PA-AA, Kattowitz 63A, 95h.

41 Page 3 of the protocol, 14. Apr. 1930, PA-AA Warschau, 176, n.p.

42 Wolfahrtsdienst, 9 Nov. 1929, R 31044, MF 3, 83-4.

43 Deutsches Konsulat Katt., 17 Feb. 1930, PA-AA, R 31044, MF 3, 87.

44 Nowiny Codzienne 116 (3 July 1934), German Trans., APO 1, 155, 127.

45 Sprawozdanie z zebrania Bund deutscher Osten, 14 June 1937, Archiwum Państowe w Katowicach (APK), 38/I, $390,61$. Zahra, Kidnapped Souls, 3, 148-9 and Tara Zahra, "Each Nation Only Cares For Its Own”: Empire, Nation, and Child Welfare Activism in the Bohemian Lands, 1900-1918', American Historical Review, 111 (Dec. 2006), 1379.

${ }^{46}$ Quoted from a speech by Stefan Kalina, board of directors member of ZOKZ in Warsaw, in Zjazd ZOKZ, 22 Apr. 1928, APK 27/I, 54, 9.
} 
at little expense. To rally urban children from low-income families, the state offered vacations at reduced prices or even completely free of charge. ${ }^{47}$

Such material, incentive-based strategies led German officials to accuse the Poles of stealing German children. There are plenty such allegations in the internal reports of German state agents in the region. One of the most eminent observers of Polonisation politics in German Upper Silesia, Karl Sczodrok, wrote the following in a 1935 report: 'in their work in recruiting children, the Poles often take advantage of the neediness of large German families in the border areas and thereby send out children who are German in their essence (urdeutsche Kinder) along with the Polish ones. ${ }^{48}$ Such a statement echoed similar reports from previous years. A press article from 1931 had scorned gullible parents, especially in working-class urban areas, who were quick to take advantage of a 'cheap holiday vacation' for their children, presented to them in 'rosy colours' by Polish agitators. ${ }^{49}$ Alarm about parents acting not out of patriotic but consumer incentives was common to nationalists on both sides of the border and hardly limited to this summer camp contest. Similar fears also affected the struggle over majority/minority schools in linguistically-mixed and religiously homogenous regions, where there was no reliable way of distinguishing Pole from German.

Once July came, Polish activists assembled the campers in the German Upper Silesian border city of Beuthen (Bytom) before taking them just fifteen kilometres across the border to Katowice (Kattowitz), the administrative capital of the Polish regional district (województwo) of (Upper) Silesia. These children travelled on the special trains that both parties had agreed to as part of the exchange accords. Upon arrival, they were greeted with a ceremonious welcome and integrated with children from elsewhere in Poland and abroad, most of them from Polish Upper Silesia. ${ }^{50}$ They were then dispersed among various summer camps located across the nation. The regions that received the highest volume of children tended to be those with rich natural or cultural landmarks, such as the districts of Silesia (particularly the mountainous border area with Czechoslvakia), Poznań, Krakow, Pomerania and Warsaw. Within each region the camps were scattered among rural districts (powiats), with most receiving fewer than a hundred campers. ${ }^{51}$ Such a scheme promoted national integration by allowing children to experience new regions and to mix with peers from other areas of the country.

Inside the camps the children were quartered mostly in school buildings, although sometimes also in Catholic cloisters and convents or with local families. People of various professions served as their adult chaperones, particularly teachers and Catholic priests, nuns and monks. There is, however, little indication that prayer or religious education played a central role in the camp experience. In fact, Polish and German reports demonstrate that the campers' activities and everyday routines were those typical of summer camp. They included engagement in sport, swimming, hiking, dancing and singing, as well as excursions to far-away places of interest, such as Krakow, Warsaw, Zakopane and the Baltic Sea. A typical memoir about the camp routine was written by camper Teresa Strzelczyk (who was about eleven years old), who in 1931 spent the summer in Ostrowiec (Kielce regional district), where she stayed in a newly-built school building with twenty of her female peers:

We were awakened each morning at 7. We did physical exercises (Turn) every day. After breakfast there was a chatting session. A woman taught us Polish history and taught us to read [Polish]. Not far from us there was a great forest. We went there every day and played ball. The time passed so quickly. On rainy days we stayed home and learned songs. The food was tasty. After lunch we would have a rest. Each day we were visited by the hosts. Each Sunday we had an excursion.

\footnotetext{
47 Regierungspräsidium (RP) reports, 30 Jan. 1934, APO 1, 155, 163 and 22 Jan. 1935, Ibid., 165.

48 Karl Sczodrok, Übersicht über die polnische Arbeit in Oberschlesien, 1935, BA, R 153, 1302, n.p.

49 RP report, 30 Jan 1935, APO 1, 155, 163, RP report, 22 Jan. 1935, ibid., 165. 'Schlimme Erfahrungen: Polnische Kinderverschickungen. Wie die deutschen Kinder in polnischen Ferienkolonien bearbeitet wurden', Oberschlesische Volksstimme, 9 Aug. 1931, APO 1, 155, 29.

50 Kommunale Polizeidirektor to OP, 21 July 1933, APO 1, 155, 105; Sprawozdanie z Akcji Kolonijnej . . 1931, 19-22.

51 Ibid., 19-22; Sprawozdanie . . 1938, 6-7.
} 
When we were going far, we would leave already at 7 in the morning. On the day before the excursion we were photographed. ${ }^{52}$

Written in German, little Teresa's testimony was an assignment issued by her school teacher upon her return home to Bobrek on the outskirts of Beuthen. German state activists had teachers act as their informers in their quest to find out what kind of political indoctrination the children had been subjected to in Poland. By collecting such testimonies and the printed material the children brought back with them, officials aimed to collect evidence of how anti-German sentiment saturated history lessons, songs and other patriotic activities at Polish summer camps. For example, some children learned to sing the infamously Germanophobic 'Rota' song. Written by the poet and novelist Maria Konopicka, its lyrics vow 'not to give up the land, from which our people originated', 'not to let the enemy Germanise us and our children' and 'not to let the German spit in our face'. ${ }^{53}$ Some were also taught a revanchist song entitled 'Silesia', whose lyrics lament that although German Upper Silesia 'was and remains Polish', it is 'separated from its motherland', but nevertheless 'cares for its Polish language', even as it had been 'infiltrated with foreign [German] words' ${ }^{54}$ Polish documents confirm that lessons arguing for the 'Polishness' of the entire region and celebrating the heroism of the Silesian Uprisings of 1921 were part of the curriculum at summer camps. ${ }^{55}$

German state officials accused their Polish counterparts of violating the rules of the exchange with such 'slandering material' (Hetzmaterial). Although they protested to the Polish government that campers were subjected to unwarranted political propaganda, they were not able to prevent Defence League-coordinated summer camps from continuing to promote Germanophobic nationalism. ${ }^{56}$ Nevertheless, as the youth exchange allowed them to import their own campers from across from the Polish border, German state agents did not terminate the youth exchange. ${ }^{57}$ Instead, they tried to publicly discredit the Polish summer camp programme and discourage parents from sending their children.

\section{War on the Happy Camper: The Media Offense on the Polish Summer Camp Experience}

The growing number of children participating in the Polish camps, which German state agents noticed especially during the depression years, heightened the Germans' suspicion that the Poles were attracting the wrong children. ${ }^{58}$ German officials noted with alarm that the vast majority of those attending Polish camps were pupils at German (majority) schools in German Upper Silesia. For example, in 1933 authorities noted that only 100 of them were from Polish minority schools, while the rest (over 550 according to Polish Defence League statistics) attended ordinary German schools. ${ }^{59}$ In addition, German activists who surveyed the gathering place in Beuthen for children travelling to Poland reported hearing widespread speaking of German among them. Karl Sczodrok noted that Polish activists tolerated this even at the summer camps in Poland in order to attract more children from across the border. ${ }^{60}$ To be sure, German activists were fully aware that spoken language was not a marker of national identity in this bilingual borderland. Nevertheless, they regarded language use as indicating a child's 'German ethos' (deutsche Gesinnung), or, in other words, his or her promise of becoming a 'full German' if given a proper cultural and patriotic upbringing. ${ }^{61}$ In fact, in 1933 German state agents

\footnotetext{
52 Teresa Strzelczyk, 'Mein Aufenthalt in Polen', circa 1 Aug.1931, APO 1, 155, 37.

53 Bericht des Lehrers Wybraniec, 25 Aug. 1932, APO 1, 155, 67-9. See also APO 1, 155, 36-7.

54 Ibid., 67-9.

55 Kolonia letnia w Czatkowicach, July 1937, APK 81 Atka Miasta Katowic, 175, 42.

56 OP to Pr. MdI, 24 Oct. 1932, APO 1, 155, 70-2; Deutsches Konsulat Katt. to Auswärtiger Amt, 15 July 1929, R 31044, MF 2, 46.

57 Wolfahrtsdienst, 9 Nov. 1929, R 31044, MF 3, 83-4.

58 Polizeipräsident to OP, 19 Aug. 1931, APO 1, 155, 27.

59 OP to RP, 4 Sept. 1933, APO 1, 155, 115 and PZZ, Sprawozdanie . . . 1938, 4.

60 Sczodrok, Übersicht . . 1935, BA, R 153, 1302, n.p.

61 OP to Pr. MdI., 2 June 1933, APO 1, 155, 82. On the use of Gesinnung (ethos or attitude) in Upper Silesia, see Wilson, Frontiers of Violence, 96-7.
} 
claimed that 95 per cent of Upper Silesians who spoke Polish (in addition to German) were actually 'German-minded' (Deutschgesinnt). ${ }^{62}$

Building on this belief that language reflected potential national identity, the Germans considered almost all children to be fair game for rallying to their camps. They therefore worked to dissuade parents in German Upper Silesia from sending their children to Poland. Without making much of an effort to appeal to German patriotism, they focused instead on slandering and degrading the summer camp experience in Poland. To do this, they tapped into camper stories, like that of little Teresa cited above, which teachers and school inspectors collected for the state. Most accounts were, like Teresa's, apolitical happy camper stories, which recalled summer activities from dancing and sports, hikes and trips, to storytelling and games. Some children mentioned they would like to go back next summer. ${ }^{63}$ The inspectors and teachers disregarded these quite ordinary recollections, however, and searched for any details they could turn into stories of child oppression and 'us' versus 'them' narratives of struggle. For example, one school inspector from Bobrek added a grain of such political drama in his summary of such mundane camper stories by emphasising how the Polish chaperones forced campers to praise Poland in 'outrageous ways' and sing 'songs slandering everything German'. ${ }^{64}$ Likewise, this official selectively drew on aspects of these children's stories to portray a moment of patriotic defiance during which a child responded to his chauvinist Polish chaperone, 'who could not boast enough about Poland's advantages vis-à-vis Germany', with a mocking question: 'do you guys also have a zeppelin?'65

German activists stumbled on a stroke of luck in their search for sad camper stories in August of 1931, when children returning from the Mały Kack camp near the port city of Gdynia (Gdingen) expressed some dissatisfaction. Activists were quick to use these complaints as the basis for an extensive article, entitled 'Awful Experiences', published in Western Upper Silesia's major newspaper, the The Upper Silesian People's Voice (Oberschlesische Volksstimme). This slandering report claimed that the children stayed in dirty, messy, overcrowded, even flea-infested school buildings, ate disgusting food and were maltreated by nasty Polish chaperones, who punished and even beat those who refused to sing Polish patriotic songs. Attempting to raise public outrage by tapping into Upper Silesia's conservative Catholic values, the article noted that at the beach children were immorally subjected to witnessing what 'they had never seen before': women sunbathing topless. This article culminated with an exposé of the Polish camp's purposeful political agenda imposed on campers, namely, 'nationalist indoctrination' and 'anti-German' irredentist propaganda, such as claiming that Poland would recover its 'beautiful, stolen Polish coast' along the Baltic. ${ }^{66}$

This article caused outrage among Polish minority activists in German Upper Silesia. They gathered some twelve of their own children, who had recently returned from the Mały Kack camp, and staged an indoor political rally on the outskirts of Hindenburg (Zabrze). As reported by the German police, they had these children affirm that, contrary to the 'lies' and 'pure slander against Poles in Germany' of Oberschlesische Volksstimme, they had enjoyed an all-around wonderful summer experience in Poland. ${ }^{67}$ About a month later the minority newspaper in German Upper Silesia, Everyday News (Nowiny Codzienne), published an article titled 'Corrections of the Oberschlesische Volkstimme's Lies' in an effort to reassure parents - Polish-speaking ones at least - that based on camper testimonies, the children at Mały Kack had been well cared for. In fact, as proof of this, the paper reported that they 'had all gained from 1 to 2 , and even 3.60 kilograms, in weight'. ${ }^{6}$

\footnotetext{
62 OP to Pr. MdI., 2 June 1933, APO 1, 155, 82.

63 See children's accounts and official comments on camper experiences in 28 Aug. 1931, APO 155, 38ff.; Minderheitsschule to Herrn Schulrat Schmukalla, 15 Sept. 1933, APO 155, 116-7; OP to MdI, 24 Feb. 1934, 121-2; RP to Reichsminister für Wissenschaft, Erziehung, und Volksbildung, 30 Jan 1934, APO 155, $163 \mathrm{ff}$.

64 Gez. Wiench, Konrektor, Bobrek, circa 28 Aug. 1931, APO 1, 155, 37.

65 Ibid., 37.

66 'Schlimme Erfahrungen', Oberschlesische Volksstimme, 217 (9 Aug. 1931) in Polizeipräsident to OP, 28 Sept. 1931, APO 1, $155,28-9$.

67 Ibid., 28.

68 Übersetzung aus Nowiny Codzienne 216 (20 Sept. 1931), APO 1, 155, 31.
} 
Newspapers on the Polish side of the border placed particular emphasis on weight gain in an effort to support the summer camps' claim to be pursuing an essentially humanitarian mission. Next to 'anchoring Polishness in our western territories' and 'tying' Poles from Germany to Poland, the Defence League emphasised in its daily, Western Poland (Polska Zachodnia), that it was providing welfare, health and nutrition to children from needy families, particularly those from overcrowded and polluted urban areas. ${ }^{69}$ For example, during the summer of 1931 the Defence League claimed that 'all [camp] children go back home reluctantly ... but with new strength (each child gained three kilograms)'. ${ }^{70}$ These numbers were quite accurate. The Defence League kept meticulous records of average weight gain per child at each camp, which were published as part of the 'proceedings from the summer camp campaign'. ${ }^{71}$ This display of state welfare services provided to 'Polish' (or at least 'Poloniseable') youth from within and without Poland's borders went hand-in-hand with nationalism. It resonated in particular with a nationalist tradition of fighting the polluting and impoverishing effects of industrialisation since the late nineteenth century. But the immediate goal of this promotional effort was to rally parents to send their children to the summer camps. And Polish state agents were quite successful in doing so. After 1933 their success alarmed the Nazi regime. Germany's own borderland activists now stepped up their effort in the struggle for campers by introducing an array of measures marked by a level of force and chicanery that was unprecedented, at least when compared to the Weimar era.

\section{Between Soft and Hard Power: The Struggle Over Campers during the Nazi Era}

In 1934 Nazi Germany signed a non-aggression pact with Poland. This reinforced cooperation between the two countries on common efforts, including the children's summer camp exchange. At the same time Germany's Nazified authorities stepped up their efforts in the struggle for campers. Next to the Prussian State government, the newly created National Socialist People's Welfare agency (Nationalsozialistische Volkswohlfahrt; NSV), emerged as the main agency coordinating Nazi Germany's outreach. In German Upper Silesia German nationalists engaged Polish activists in an invigorated contest for campers. Their aim was to have 'children of German descent or those from the nationally indifferent layer-in-between that were sent to Poland [this year] put on the list of children attending camps in Germany next year. ${ }^{72}$ To this end they adopted a strategy similar to the one already used by their Polish competitors. To entice parents to give them their children for the summer, they offered them an affordable vacation that would beat the one in Poland. According to state directives, children who had spent the previous summer at beautiful natural and recreational sites in Poland like the Tatra Mountains or the Baltic coast were to be offered stays at similar mountainous or beach resorts in Germany next year. ${ }^{73}$

Under Nazi leadership, this rallying effort took a confrontational and intimidating turn. From 1933 German schoolteachers not only collected camper stories, they also pursued parents who sent their children to Poland. They threatened these parents with job loss and their children with reprisals against their education and futures. ${ }^{74}$ Nazi officials confronted German state employees who sent their children to Polish summer camps. A good example is the story of an employee of the magistrate of Gleiwitz (Gliwice), who was also a liaison (Vertrauensmann) with the border area political police. In 1935 the police questioned him for having sent his son to a camp in the green mountains of Zakopane. He swore that he had no patriotic or political motives but rather was swayed by a poster he saw hanging in front of the Polish consulate, which promised a memorable and healthy summer for an affordable price (7 Reichsmarks). He assured them that his son had not been 'Polonised' but, on the

\footnotetext{
69 Quoted from Übersetzung aus Polska Zachodnia 142 (4 June 1931), APO 1, 155, 7.

70 This referred to children returning from camp stays during May and June. Translation from Polska Zachodnia, 152 (14 June 1931), APO 1, 155, 6.

71 See, for example, Sprawozdanie z Akcji Kolonijnej . . 1931, 15.

72 Pr. MdI. to OP, 26 Mar. 1935, APO 1, 155, 170.

73 Ibid., 170.

74 Katholische Volksschule Dt. Müllmen bei Oberglogau to RP, 4 July 1933, APO 1, 155, 97.
} 
contrary, spoke German every day during his time in Poland. Moreover, he insisted that his choice to send his child to a Polish summer camp was not a bad one, since this camper returned home looking happier, healthier and bulkier. ${ }^{75}$ Beyond such threats and intimidation, however, there is no record of any severe state action taken against this government employee or any other parents who sent their children to Poland. Particularly in Upper Silesia, state activists understood only too well that, in the words of official correspondence, 'only in the most seldom of cases are signups to send children [to summer camp] determined on national-political grounds but rather more often by economic and health factors' ${ }^{76}$ Such a paradox of coming to terms with and adapting to national indifference while at the same time confronting it with intimidation was quite common among Nazi officials.

On the other side of the border, in Polish Upper Silesia, the Volksbund as well as the Nazi German minority organisation, the Young German Party (Jungdeutsche Partei; JdP), were active in rallying children to travel to summer camp or a German host family in the mountains, countryside or beaches of the Reich. Unlike Polish minority activists across the border in Germany, who eagerly took local children irrespective of the language they spoke and level of their family's patriotic conviction, the JdP aimed to exclude children of 'parents whose Germandom ultimately hinged on the state of the economy'. ${ }^{77}$ Nevertheless, in practice, far more children were taken than just the 'patriotic Germans' the JdP rallied. According to official reports, not even a tenth of campers going to Germany in 1936 were members of the JdP. ${ }^{78}$ Moreover, according to Prussian state records, the number of children with Polish citizenship attending camps in Germany rose steadily from 3,526 in 1933 to 6,380 two years later. ${ }^{79}$ Most children from Polish Upper Silesia joined those from the larger German (Upper and Lower) Silesia region to travel to camps in Bavaria. ${ }^{80}$

Polish state agents also stepped up their efforts. In response to criticism from their competitors across the border, they paid more attention to conditions at their camps and the welfare of campers, especially those from abroad. Even internal German state records from 1934 noted an improvement in the quality of children's summer vacations, and certainly also happier campers returning to Germany. ${ }^{81}$ At the grassroots of the German side of the border, Polish minority organisations like the Polish Catholic School Association intensified their rallying efforts by going door to door with their camp offers that targeted, in particular, low-income families and the children of the unemployed. $^{82}$

The most blatant engagement in the contest for campers came from the Polish-language press in both parts of Upper Silesia. During the Weimar era it was mainly the German newspapers that complained of foul play on the part of Polish activists with regard to the children's exchange. After the Nazi takeover, however, their Polish counterparts had little trouble in finding grievances of their own against the new regime's activists. They accused them of violating the rules of the exchange by turning German summer camps into centres for the 'Nazification' of youth. In the summer of 1933 the leading Katowice dailies, Polonia and Polska Zachodnia, reported that upon arriving to the Beuthen train station from their trip from Polish Upper Silesia, the campers (1,157 Polish citizens and 261 German citizens) were greeted by NSV activists with 'Heil Hitler' shouts, received little swastika flags from them and engaged in a singalong of 'We Want to Strike Poland Triumphally' (Siegreich wollen wir Polen schlagen), an aggressive army song often adapted to target whatever enemy nation its singers wanted to mock. ${ }^{83}$

\footnotetext{
75 An die Kreisschulinspektion, 22 Jan. 1935, APO 1, 155, 165.

76 OP to Pr. MdI, 2 June 1933, APO 1, 155, 82.

77 Milbradt to Wohlfahrtsdienst, 26 May 1936, PA-AA, Kattowitz 63A, 95d-95e.

78 Ibid., 95d-95e

79 Deutscher Wolfahrtsdienst report, 27 May 1936, PA-AA, Kattowitz 63A, 95h.

80 Konsulat Reczypospolitej Polski w Opolu (Polski Konsulat Opole), dot. wyjazdu dzieci ze Śląska Opolskiego na kolonje letnie do Niemiec, 30 July 1936, Archiwum Akt Nowych (AAN) 474, 374, 141.

81 RP, Verschickung deutscher Kinder nach Polen, 30 Jan 1934, APO 1, 155, 163-4.

82 OP to RP, 4 Sept. 1933, APO 1, 155, 114-5.

83 OP, Übersetzung aus Polonia 3142 (21 June 1933) and Polska Zachodnia 169 (21 June 1933), APO 1, 155, 83-6.
} 
Two days later Breslau's leading German-language daily, Schlesische Zeitung, delivered a direct response. It confirmed all allegations, except those about the aggressive song. Instead, it claimed, the children sang a Silesian regional ballad (Heimatlied). However, the paper refuted any accusations of foul play by reminding readers that Germans had tolerated similar political displays from the Poles, including the distribution of national symbols and singing of slanderous anti-German patriotic songs at Polish summer camps, as well as the fact that these camps were coordinated by the Germanophobic Western Territories Defence League. ${ }^{84}$ This tit-for-tat in the press, alleging violations of the spirit of the children's exchange accords, continued for years. This press war marked perhaps the most conspicuous feature of the contest over campers during the Nazi era before 1939.

Polish officials, responding to mounting complaints about Nazi Germany's violation of the rules of the children's exchange, threatened to end this youth effort altogether. This alarmed German state agents. In their internal reports they warned that nothing should be done to give the Polish side reason for grievance. ${ }^{85}$ However, such admonitions were futile. The Nazification of the agents of the German summer camp effort and the propaganda directed toward children made just about any aspect of it a reason for Polish state objection. For example, in 1936 Polish officials complained that German activists dressed their campers from Polish Upper Silesia in 'JdP uniforms': black shorts and brown shirts, which was also the common garb for the Hitler Youth (who indeed often joined these children in camp activities). ${ }^{86}$ Such complaints had little effect, however. Rather, these uniforms were commonly worn by campers.

The summer of 1938 saw the last German-Polish children's exchange. The 1922 Geneva Convention had expired the previous year. Without this agreement, which had guaranteed mutual rights of German and Polish minorities in Upper Silesia, these minorities' members and organisations were subject to varying degrees of chicanery and persecution from the authoritarian nationalist governments and their radical activists on both sides of the border, but particularly in Nazi Germany. As League of Nations-guaranteed minority protection ceased, parents in German Upper Silesia became fearful, and thus were reluctant to send their children to Polish summer camps. ${ }^{87}$ Consequently, the Polish government officially refused to take part in the children's exchange for the summer of $1939 .{ }^{88}$ In response, the Nazi-controlled press on the German side of the border added the label of 'child unfriendly' to the long-list of slander with which they barraged Poland in the last months before Germany invaded Poland in September $1939 .^{89}$

\section{Conclusion}

The interwar history of the German-Polish children's exchange is a prime example of how a programme of cultural diplomacy in fact served as a tool of cross-border nationalisation politics, or 'external homeland nationalism', in interwar Europe. The summer camps resembled many other cross-border youth exchanges at the time, which were celebrated as promoting peace and international understanding. ${ }^{90}$ Germany's and Poland's summer camps, however, served German and Polish state intrusion into child rearing practices on the 'other's' side of the border, with particular attention to linguistic, cultural and patriotic education, and, ultimately, cultural maintenance. In order to maintain

\footnotetext{
84 'Deutsche Ferienkinder aus Ostoberschlesien', Schlesische Zeitung, 312 (23 June 1933) in APO 1, $155,87$.

85 Pr. MdI. to OP, 20 Mar. 1935, APO 1, 155, 170; RP, Verschickung von Kindern nach Polen, 4 Apr. 1935, APO 1, 155, 171; Übersetzung aus Polska Zachodnia 207 (31 July 1936), 194.

86 Polski Konsulat Opole to Polska Ambasada Berlin, 6 Aug. 1936, AAN 474, 3938, 142.

87 Records demonstrate a 40 per cent decline in children travelling from Silesia (Upper and Lower, but most from the former) to Poland from 1937 to 1938. See Sprawozdanie . . 1938, 4; ZOKZ, Sprawozdanie 1 Nov 1931 - 31 Dec. 1938, APK 38/I, 153, 191; Übersetzung aus Nowiny Codzienne 60 (14 Mar 1937), APO 1, 155, 214.

88 Polski Konsulat Opole to Ministerstwo Spraw Zagranicznych, 19 Jan. 1939, AAN 482, 110, 11.

89 'Polnische Behörden als "Kinderfreunde"', Ostdeutsche Morgenpost, 191 (14 Jul 1939) in APO 1191, $1939,165$.

90 See, for example, Zsolt Nagy's discussion of the International Youth Jamboree in Hungary and Elisabeth Piller's account of transatlantic student exchanges in this special issue.
} 
claims to these areas both states pursued a common nationalisation-oriented cultural politics Volkstumspolitik - to prevent the 'de-nationalisation', or assimilation into the 'other's' culture and society, of children they claimed for their nation. As part of this 'external nationalist' interventionist policy, both states promoted the proliferation of their respective schools, cultural organisations and language across the border. As such, Polish-German summer camps illustrate how interwar efforts to undo (or enforce) the territorial provisions of the peace treaties prompted new attention and commitment to cultural diplomacy.

The summer camp exchange had a distinctly transnational character. It marked a reciprocal German-Polish youth tourist venture: an effort to have each state's respective 'national minority' schoolchildren travel from the 'other's' side of the border home to their 'motherland' for the summertime school recess. These children joined each nation's summer camps, which were never meant exclusively for them. Rather, for both states, they served a larger mission to provide welfare - such as a healthy fresh-air environment, nutrition, recreation, leisure and culture - to disadvantaged, lower-class youths, mostly from within their borders.

Nevertheless, this effort to transport children from across the border had its own unique political implications. It marked an aspect of German-Polish cultural diplomacy that was fundamentally driven by these states' mutually antagonistic irredentist politics. Paradoxically, this inherent fuelling force of bilateral territorial conflict also promoted and depended on cooperation and collaboration between both states. In fact, for the sake of the exchange, the two states recognised each other's claims to populations ('national minorities') within their own borderlands, and thus inadvertently also to these contested territories. Such a risky concession nevertheless enabled each party to use children from across the border to fuel the flames of ethnic nationalism: these cross-border youths' presence in each party's summer camps symbolised their connection to their respective 'motherland,' and, in turn, the latter's extension beyond the borders drawn at Versailles.

As such, the German-Polish children's summer exchange also exemplifies the mobilisation of children for nationalist conflict and, in particular, territorial contestation and 'minority' politics. Unlike the pressure and duty-filled school year, for children, the summer break was an exciting time of freedom and leisure, of spiritual renewal and recreation, and of joy, new experiences and memories. German and Polish nationalists were quick to exploit this scenario of leisure and tourism for winning the hearts and minds of borderland children. In Upper Silesia, a region of no clear-cut national communal boundaries, this bilateral struggle for the camper began with each side's annual effort to mobilise parents to send their children to 'our' side's camps and not 'theirs.' Given that in this borderless region just about any child was their potential camper, German and Polish activists catered specifically to the Silesian parents' nationally indifferent mindset. Putting aside futile appeals to patriotism and national identity, each side instead played up the material and experiential utility of its summer camps and sought to tarnish the image of those of its competitor. In consequence, competition and conflict, marked by a tit-for-tat barrage of slurs and allegations, became the real face of what was officially supposed to be a peaceful and fair youth exchange.

Neither side hesitated to use children for such nationalist propaganda. In fact, both capitalised on the ordinary and fundamentally apolitical behaviour of children. They portrayed innocent child expressions of joy at summer camp as declarations of patriotism and national option, just as they used juvenile gestures of sorrow and discontent to slander the 'other'. Even the bodies of children did not escape political exploitation, as nationalists used children's weight gain to boast about the health benefits of remaining connected to the 'motherland'.

Such politicisation of children's leisure only set the stage for a more intensive state mobilisation of youth for borderland (re-)nationalisation efforts, which started with Nazi Germany's attack on Poland and ended with communist Poland's annexation of Upper Silesia and other formerly German borderlands after the Second World War. Both regimes continued to nationalise children by establishing special Germanisation and Polonisation school curricula for the nationally indifferent, most of whom were not expelled from Upper Silesia but rather were to be assimilated into the new German/Polish national communities. Moreover, some of the same organisations active in the interwar children's 
summer exchange, particularly Nazi activist groups and the Defence League (called the Polish Western League after 1934), continued to mobilise children for their social engineering efforts. They used children to help expel the unwanted 'other' and resettle their national kin, as well as (re)shape and (re) build national landscapes and raise model (Nazi German or national and communist Polish) citizens in Upper Silesia and other borderlands. During and after the war, respectively, Hitler Youth and Polish scouts were active in removing all public displays and traces of the 'other's' language (not just Polish/ German but also Yiddish), personal and place names, as well as helping resettlers (e.g. Hitler's 'Umsielder' from Bessarabia and the Soviet Union and Poles from east of the post-war Curzon Line), who were sent to settle former German eastern borderlands. ${ }^{91}$ All of this underlines the paradox of the interwar children's exchange: although it provided mostly child-friendly, fun and healthy summer leisure facilities, which generally turned out happy campers and satisfied parents, it was also a nationalist instrument of constructing firm ethnic borders and homogenous nation states in a Wilsonian Central Europe. ${ }^{92}$ In this way the German-Polish case - particularly intense though it may have been - also highlights a broader defining feature and driving force of interwar cultural diplomacy: the interplay of international cooperation and competition.

Acknowledgments. I would like to thank Paul Hanebrink and Andrew Demshuk for their helpful and insightful comments on earlier drafts, Elisabeth Piller for her generous assistance during the revision process and the anonymous readers for their meticulous feedback and support. Open Access funding provided by the Qatar National Library.

\footnotetext{
91 On youth activism in the Germanisation (1939-1945) and Polonisation (1945-1953), see Polak-Springer, Recovered Territory, 165-6, 171 and 214; Harvey, Women and the Nazi East, 191-260; Zahra, Kidnapped Souls, 169-79 and “"Each Nation Only Cares For Its Own”, 528-38.

92 On Nazi war and post-war Polish mobilisation of youth for nationalisation in Upper Silesia, see Polak-Springer, Recovered Territory, 171, 214-5.
}

Cite this article: Polak-Springer P (2021). Gain Weight, Have Fun, Discover the Motherland: The German-Polish Children's Summer Camp Exchange and Interwar Era Revisionism. Contemporary European History 30, 214-230. https://doi.org/ $10.1017 /$ S096077732000051X 